\title{
Developmental Coordination Disorder: Is Clumsy Motor Behavior Caused By a Lesion of the Brain At Early Age?
}

\author{
Mijna Hadders-Algra \\ Department of Neurology - Developmental Neurology, University of Groningen, \\ Groningen, The Netherlands
}

\section{SUMMARY}

Children presenting with Developmental Coordination Disorder or clumsiness often exhibit signs of minor neurological dysfunction (MND). The data of the Groningen Perinatal Project, a long-term follow-up project on the relations between prenatal and perinatal adversities and neurological, behavioral, and cognitive development revealed that two basic forms of MND can be distinguished: simple and complex MND. During school age children with simple $M N D$ are characterized by the presence of one or two dysfunctional clusters of MND, in adolescence by the presence of choreiform dyskinesia or hypotonia. Probably the major sources of origin of simple MND are genetic constitution and stress during early life. Simple MND might reflect the lower tail of the normal distribution of the quality of non-pathological brain function. In line with this hypothesis is the finding that simple MND is associated with only a moderately increased risk for learningand behavioral problems. Children with complex MND present at school age with at least three dysfunctional clusters of MND, in adolescence with problems in fine manipulation or coordination. Perinatal adversities play an

Reprint requests to: Prof. Dr. Mijna Hadders-Algra, Developmental Neurology, University Hospital Groningen, Hanzeplein 1, 9713 GZ Groningen, The Netherlands; e-mail: m.hadders-algra@med.rug.nl evident etiological role in the development of complex MND, suggesting that it might be attributed to a lesion of the brain at early age. In line with this idea is the finding that complex MND shows a strong correlation with attention and learning problems.

\section{KEYWORDS}

minor neurological dysfunction, soft neurological signs, prenatal stress, preterm birth, intrauterine growth retardation

\section{INTRODUCTION}

During the last century many terms, such as dyspraxia, minimal brain dysfunction, sensory integrative dysfunction, and developmental coordination disorder have been used to describe children with clumsy motor behavior (Geuze et al., 2001; Henderson \& Henderson, 2003). But gradually it was realized that the heterogeneity in labels was confusing and counterproductive. Participants at an international, multidisciplinary consensus meeting in 1994 agreed to use the DSMIV term Developmental Coordination Disorder or DCD (American Psychiatric Association, 1994; Polatajko et al., 1995). The term DCD in general refers to children with normal intelligence who have poor motor coordination without evidence of frank neurological pathology, such as cerebral 
palsy or muscular dystrophy. ${ }^{1}$ The motor problems of children with DCD are so serious that they affect daily activities at home and at school.

The heterogeneity in terminology has hampered research, such as the search for etiological factors and the understanding of pathogenetic mechanisms of clumsy motor behavior or DCD. What percentage of DCD cases can be attributed to damage of the nervous system remains to be determined, and for those cases in which this attribution can be made, whether the damage occurred in prenatal, perinatal, or early postnatal development. At present these questions can not be answered. But, recent research allows for the answering of a relatively close question: what part of minor neurological dysfunction in childhood is caused by a lesion of the brain at early age? The aim of the present paper is to discuss the latter question.

\section{MINOR NEUROLOGICAL DYSFUNCTION}

Minor neurological dysfunctions can be detected during a standardized and age-specific neurological examination. These dysfunctions are also known as soft neurological signs. But the term MND is preferable to the expression soft neurological signs as the word soft has the fallacious connotation of ambiguity (Touwen, 1987). Examples of assessment techniques for the detection of MND are the assessments according to Touwen (1979) or Herzig (1987) for school age children or the technique of Hempel (1993) for children at pre-school age. The assessments require a thorough knowledge of the age-specific properties of the child's neuromotor performance. Essential to the diagnosis of MND is the presence of a cluster of signs of dysfunction. This means that the presence of a single sign of dysfunction,

\footnotetext{
1 The diagnosis DCD can also be given to children with mental retardation, in case the motor difficulties are in excess of those usually associated with mental retardation (DSM-IV).
}

such as the isolated presence of a Babinski sign, does not allow for the label MND. The clusters are organized according to the functional, neurobehavioral subsystems of the nervous system used in clinical practice (Touwen, 1979; Hadders-Algra et al., 1988a). The inter-oberserver agree-ment on the presence or absence of a cluster of dysfunctions is high (Hadders-Algra \& Groothuis, 1999). Descriptions of the clusters at pre-school age and beyond are presented in Tables 1 and 2 .

The data of the Groningen Perinatal Project (GPP), a long-term follow-up project on relations between prenatal and perinatal adversities and neurological, behavioral and cognitive development indicated that basically two distinct forms of MND can be distinguished: simple MND and complex MND (Hadders-Algra, 2002). In the following paragraphs the clinical relevance will be explained, especially that of the complex form of MND.

The criteria for simple and complex MND are age specific. This phenomenon is due to the developmental changes in the nervous system, which induce changes in the expression and prevalence of MND. Extrapolations of the data of the Groningen Perinatal Project (GPP) to the general population (see Hadders-Algra \& Touwen, 1992) indicate that the rate of MND at pre-school age is relatively low ( $5 \%$ to $7 \%$ ). During the following years, the frequency of MND shows a steady increase, reaching its peak of about $25 \%$ shortly before the emergence of puberty. The agedependent increase in the prevalence of MND runs parallel to - and is presumably related to-the agedependent increase in the complexity of brain function. The onset of puberty induces a substantial decline in the number of dysfunctional clusters of MND, so that at the age of 14 years only $7 \%$ to $8 \%$ of children exhibit MND. In addition, most adolescent children with MND present with only one dysfunctional cluster. Possibly the decline in MND around puberty is 


\section{TABLE 1}

Functional, i.e. neurobehavioral clusters of MND, based on the neurological examination of Hempel (1993) for children aged 11/2 - 4 years, adapted from Hadders-Algra et al. (2003)

\begin{tabular}{|c|c|c|}
\hline Cluster of dysfunction & Signs & Criteria for dysfunctional cluster \\
\hline $\begin{array}{l}\text { Dysfunctional muscle } \\
\text { tone regulation }\end{array}$ & $\begin{array}{l}\text { Abnormalities in muscle tone } \\
\text { Abnormal posture during sitting, crawling, standing } \\
\text { and walking }\end{array}$ & $\begin{array}{l}\text { One or two of the following: } \\
\text { - consistent mild deviations in } \\
\text { muscle tone } \\
\text { - consistent mild deviations in } \\
\text { posture }\end{array}$ \\
\hline Reflex abnormalities & $\begin{array}{l}\text { Abnormal intensity and/or threshold or asymmetry in: } \\
\text { - biceps reflex } \\
\text { - knee jerk } \\
\text { - ankle jerk } \\
\text { Footsole response: uni- or bilateral Babinski sign }\end{array}$ & Presence of at least two signs \\
\hline $\begin{array}{l}\text { Gross motor } \\
\text { dysfunction }\end{array}$ & $\begin{array}{l}\text { Dyscoordination of arm and leg movements during } \\
\text { crawling } \\
\text { Block-like movements of trunk during crawling, } \\
\text { standing and walking } \\
\text { Age-inadequate balance } \\
\text { Age- inadequate manoeuvrability during walking } \\
\text { Age-inadequate ability to avoid objects during walking }\end{array}$ & Presence of at least two signs \\
\hline $\begin{array}{l}\text { Fine motor } \\
\text { dysfunction }\end{array}$ & $\begin{array}{l}\text { Absent pincergrasp in } 1 \text { or } 2 \text { hands } \\
\text { Exclusive hand preference } \\
\text { Abnormal quality of arm movements } \\
\text { Poor adjustment of handopening } \\
\text { Abnormal quality of hand movements }\end{array}$ & Presence of at least two signs \\
\hline $\begin{array}{l}\text { Rarely occurring } \\
\text { miscellaneous } \\
\text { disorders }\end{array}$ & $\begin{array}{l}\text { Motor behavior of face, } \\
\text { eyes, pharynx, tongue } \\
\text { Involuntary movements, such as tremor }\end{array}$ & $\begin{array}{l}\text { Evidence of at least one of the } \\
\text { following: } \\
\text { Mild cranial nerve palsy } \\
\text { Consistent presence of tremor }\end{array}$ \\
\hline
\end{tabular}


TABLE 2

Functional, i.e., neurobehavioral clusters of MND, based on the neurological examination of Touwen (1979) for children aged 4 years and older, adapted from Hadders-Algra et al. (1988a).

\begin{tabular}{|c|c|c|}
\hline Cluster of dysfunction & Based on & Criteria for dysfunctional cluster \\
\hline $\begin{array}{l}\text { Dysfunctional muscle } \\
\text { tone regulation }\end{array}$ & $\begin{array}{l}\text { Muscle tone } \\
\text { Posture during sitting, crawling, } \\
\text { standing and walking }\end{array}$ & $\begin{array}{l}\text { One or more of the following: } \\
\text { - consistent mild deviations in } \\
\text { muscle tone } \\
\text { - consistent mild deviations in } \\
\text { posture }\end{array}$ \\
\hline Reflex abnormalities & $\begin{array}{l}\text { Abnormal intensity and/or threshold or } \\
\text { asymmetry in: } \\
\text { - biceps reflex } \\
\text { - knee jerk } \\
\text { - ankle jerk } \\
\text { Footsole response: uni- or bilateral Babinski } \\
\text { sign }\end{array}$ & Presence of at least two signs \\
\hline Choreiform dyskinesia & $\begin{array}{l}\text { Spontaneous motor behavior } \\
\text { Test with extended arms } \\
\text { Movements of face, eyes, tongue }\end{array}$ & $\begin{array}{l}\text { Presence of at least one of the } \\
\text { following } \\
\text { - Marked choreiform movements of } \\
\text { distal and facial muscles } \\
\text { - Slight or marked choreiform } \\
\text { movements of proximal muscles, } \\
\text { eyes or tongue }\end{array}$ \\
\hline Coordination problems & $\begin{array}{l}\text { Finger-nose test } \\
\text { Fingertip-touching test } \\
\text { Diadochokinesis } \\
\text { Kicking } \\
\text { Knee-heel test } \\
\text { Reaction to push (sitting, standing) } \\
\text { Romberg } \\
\text { Tandem gait } \\
\text { Standing on one leg }\end{array}$ & $\begin{array}{l}\text { Presence of age-inadequate } \\
\quad \text { performance of at least two tests }\end{array}$ \\
\hline Fine manipulative ability & $\begin{array}{l}\text { Finger-opposition test: } \\
\quad \text { - smoothness } \\
\text { - transition } \\
\text { Follow-a-finger test } \\
\text { Circle test }\end{array}$ & $\begin{array}{l}\text { Presence of age-inadequate } \\
\text { performance of at least two tests }\end{array}$ \\
\hline $\begin{array}{l}\text { Rarely occurring } \\
\text { miscellaneous disorders }\end{array}$ & $\begin{array}{l}\text { Motor behavior of face, } \\
\text { eyes, pharynx, tongue } \\
\text { Associated movements during } \\
\text { diadochokinesis, } \\
\text { finger-opposition test, walking } \\
\text { on toes or heels }\end{array}$ & $\begin{array}{l}\text { Evidence of at least one of the } \\
\text { following: } \\
\text { - Mild cranial nerve palsy } \\
\text { - Excessive amount of associated } \\
\text { movements for age }\end{array}$ \\
\hline
\end{tabular}


TABLE 3

Age specific criteria for simple and complex MND (see Hadders-Algra 2002; Hadders-Algra et al., 2003)

\begin{tabular}{||l|c|l|l||}
\hline \multicolumn{1}{|c|}{ AGE } & METHOD & \multicolumn{1}{c|}{ SIMPLE MND } & \multicolumn{1}{c||}{ COMPLEX MND } \\
\hline $1 \frac{1}{2}$ to $4 \mathrm{yr}$ & Hempel, 1993 & 1 MND cluster of dysfunction & $>1$ MND cluster of dysfunction \\
\hline $\begin{array}{l}4 \text { yr to onset of } \\
\text { puberty }\end{array}$ & Touwen, 1979 & $1-2$ MND clusters of dysfunction & $>2$ MND clusters of dysfunction \\
\hline $\begin{array}{l}\text { After onset of } \\
\text { puberty }\end{array}$ & Touwen, 1979 & $\begin{array}{l}\bullet \text { mild hypotonia } \\
\bullet\end{array}$ & $\begin{array}{l}\bullet \text { mild coordination problems } \\
\text { mild fine manipulative disability }\end{array}$ \\
\hline
\end{tabular}

mediated by the hormonal changes occurring during this phase of life (Lunsing et al. 1992; Soorani-Lunsing et al. 1993). Candidate hormones are thyroxine and estrogen. Thyroxine utilization increases during puberty, and this might affect myelination, which could result in an improvement of the neurological condition (Timiras, 1972). The onset of puberty is also accompanied by a rise in gonadal hormones, such as estrogens in girls and androgens in boys. In the brain, the androgens are metabolized into estrogens (Jacobson, 1991; Martini \& Melcangi, 1991). Recently, evidence has been accumulating that estrogens might play a positive role in response to brain injury, for instance by inducing axonal sprouting and enhancing synaptic transmission (Garcia-Segura et al. 2001). In addition, Hampson (1990) demonstrated that an increase in estrogen level can result in an improvement of motor performance. Thus, one could speculate that an increase in estrogen-level might induce a decline in MND.

Because of the developmental changes in MND, the criteria for simple and complex MND are agespecific. Before the onset of puberty the distinction is based on the number of clusters of dysfunction that the child exhibits; after the onset of pubertywhen most children with MND present with a single cluster of MND-discrimination is based on the type of dysfunction present (Table 3). Seemingly the process of puberty converts the nonspecific, quantitative expression of dysfunction of the prepubertal nervous system into a specific, qualitative, and possibly more adult-like display of brain dysfunction.

\section{SIMPLE MND}

The data of the GPP indicated that the estimated prevalence of simple MND in the general population is $15 \%$ at 9 years and $3 \%$ to $4 \%$ at 14 years (Hadders-Algra, 2002). The project revealed that only few perinatal risk-factors were associated with the development of simple MND. Simple MND turned out to be related to some extent to severe intrauterine growth retardation, namely, being born with a birthweight below the 2.3 percentile of the growth curve, an Apgar score at 3 minutes $<7$, diseases like frequent colds between the age of 9 and 12 years, a family history of neuropsychiatric disorders, and male gender (Hadders-Algra et al., 1988a; Soorani-Lunsing et al., 1993). The presence of simple MND was associated with a moderately increased risk for learning and 
behavioral problems, such as Attention Deficit Hyperactivity Disorder (ADHD; Hadders-Algra et al. 1988b; Soorani-Lunsing et al., 1994).

The GPP-findings make plausible the notion that simple MND has two major sources of origin. First, simple MND could, just like ADHD, have a substantial genetic component (cf., Faraone \& Biederman, 1998). This hypothesis might imply that simple MND represents the lower tail of the normal distribution of the quality of non-pathological brain function. The other source of origin of simple MND could be stress during early life, such as stress associated with preterm birth (see for example, Hellerud \& Storm, 2002), severe intrauterine growth retardation, mild to moderate degrees of perinatal asphyxia, or prenatal stress resulting from psychological stress of the mother.

Animal research indicates that prenatal stress can induce permanent alterations in the structure and function of the central nervous system (Weinstock, 2001). Studies in rats showed that prenatal stress induced by psychological stress of the mother does results not only in a long-term dysregulation of the hypothalamic-pituitary-adrenal axis, such as hyperreactivity to stress, but also in changes in serotonergic and noradrenergic activity in the cerebral cortex and alterations in dopaminergic activity in the striatum and prefrontal cortex (Peters, 1982; 1983; 1990; Weinstock, 2001). The results of other studies indicate that alterations in the development of the early arising monoaminergic systems (Lagercrantz \& Ringstedt, 2001) can result in permanent changes of behavior and mild balance problems (Cases et al., 1995). Prenatal stress also can induce an impaired development of the maps of body representation in the primary somatosensory cortex (Cases et al. 1998) and inappropriately developed ocular dominance columns in the visual cortex $(\mathrm{Gu} \&$ Singer, 1995). Schneider and coworkers (1992a, 1992 b; 1992c; 1993; 1998), who addressed the sequelae of prenatal stress in rhesus and squirrel monkeys, demonstrated that also in primates prenatal stress causes long-term alterations in the neurochemical make-up of the brain. The changes were accompanied by minor neuromotor dysfunctions such as balance problems, a delay in cognitive development, and behavioral abnormalities such as sleeping problems and decreased levels of explorative behavior, locomotion and social play, as well as sleeping problems.

In humans the evidence of the effect of maternal psychological stress on brain development of her offspring is as yet inconclusive (Mulder et al., 2002). The prospective studies of Zuckerman et al. (1990) and Lou et al. (1994) indicate that prenatal stressors of human life have a moderately negative effect on the neurobehavioral condition of the newborn infant. Whether this negative effect persists during further development is unclear. Retrospective studies suggest that prenatal psychological stress might have long-term consequences for brain development as they pointed to a relation between prenatal stress and an increased risk for psychiatric morbidity such as schizophrenia and depression (Huttunen \& Niskanen, 1978; Watson et al. 1999). In contrast to the equivocal effect of psychological forms of prenatal stress, multiple studies have shown that non-psychological stress during early human life has a long lasting adverse effect on the child's neuromotor condition. For instance, severe intrauterine growth retardation, which is not accompanied by abnormalities in blood flow velocity profiles in the fetal aorta, is associated with an increased risk of simple MND (HaddersAlgra et al. 1988a; Ley et al., 1996). Likewise, preterm birth and low birthweight are related to less adequate motor control and $\mathrm{DCD}$, irrespective of the presence of minor abnormalities on the neonatal ultrasound scans of the brain (Hadders-Algra et al. 1999; Holsti et al. 2002; Fallang et al. 2003.

In conclusion, simple MND might be considered to reflect a normal (non-pathological) 
but non-optimal form of brain function. For example, the front-striatal dopaminergic system may operate in a non-optimal manner. A nonoptimal brain wiring can be due to genetic constitution (e.g., Faraone \& Biederman, 1998) or to aberrant 'fetal programming' resulting from stress in early life (Kajantie et al., 2002).

\section{COMPLEX MND}

The data of the GPP indicate that the estimated prevalence of complex MND at 9 years is $6 \%$ and that at 14 years $3 \%$ to $4 \%$ (Hadders-Algra, 2002). The project revealed that complex MND has strong prenatal and perinatal roots. Complex MND is associated in particular with neonatal neurological deviancy, birth before 33 weeks gestation, and a low obstetrical optimality score (HaddersAlgra et al., 1988a; Soorani-Lunsing et al., 1993). Ley et al. (1996), who studied MND at school age in growth retarded infants, showed that the development of complex MND was associated with an absent or reversed end-diastolic blood flow velocity in the fetal aorta. Their data and those of the GPP suggest that complex MND might be the result of a lesion of the brain at early age. The association between the low obstetrical optimality score and complex MND indicates that the lesion of the brain might be the consequence of a chain of obstetrical adversities.

Similar chains of prenatal and perinatal adversities are known to play a role in the etiology of cerebral palsy (Stanley et al., 2000), which might imply that complex MND could be regarded as a borderline form of cerebral palsy. Certain perinatal adversities occur during the part of life that corresponds to the last trimester of pregnancy. In this period especially the cerebellum and periventricular regions show a high developmental activity, which is associated with an increased vulnerability to harmful conditions. A site of predilection for lesions is the central white matter (Volpe, 1995). Thus it could be surmised that at least part of complex MND might be due to an interruption of connecting fibre systems, such as the corpus callosum (Mercuri et al., 1996) or the descending systems in the internal capsule. Interestingly, a recent study indicated that lesions of the periventricular white matter in preterm infants are associated with a significant reduction of the cerebral cortical gray matter at term age (Inder et al. 1999). Also the type of dysfunctions that play a prominent role in complex MND, namely, the dysfunctions in fine manipulation and coordination (Table 3), point into a similar direction as they may reflect dysfunction of the cortico-striato-thalamo-cortical and cerebellothalamo-cortical pathways. These circuitries play a role not only in sensorimotor aspects of motor programming, movement planning, program selection, and motor memory but also in cognitive tasks involved in learning and in regulating attention (Alexander \& Crutcher, 1990; Leiner et al., 1993; Diamond, 2000). This could explain the strong association of complex MND with cognitive and attentional difficulties (HaddersAlgra et al. 1988b; Soorani-Lunsing et al., 1994).

\section{DCD, CLUMSINESS, AND MND}

Few studies have investigated the relation between clumsiness or DCD and MND. The data of the GPP indicated that teachers' reports of clumsiness are related more strongly to the child's neurological condition than are parents' reports of clumsiness (Fig. 1). Teachers considered $55 \%$ of the children with complex MND as clumsy against 13\% of children with a normal neurological condition and $28 \%$ of children with simple MND. Similar relationships between DCD and MND were reported by Jongmans et al. (1997). This group studied preterm children at the age of 6 years both 
by means of the Movement $\mathrm{ABC}$ (Henderson \& Sugden, 1992) and the Touwen (1979) neurological examination. On the basis of the Touwen assessment, a neurological optimality score was computed. On the basis of this optimality score, children were classified as neurologically normal (score $>15^{\text {th }}$ percentile), borderline (score between $5^{\text {th }}$ and $15^{\text {th }}$ percentile) and abnormal (score $<5^{\text {th }}$ percentile). The border-line scores could be interpreted as the presence of simple MND, whereas the abnormally low scores probably represented complex MND. The large majority $(92 \%)$ of children with 'complex MND' had a Movement $\mathrm{ABC}$ score below the $15^{\text {th }}$ percentile, which in general is taken as the cut-off point for DCD (see Henderson \& Henderson, 2003; Fig. 2). Their data underline that especially the children with complex
MND frequently suffer from motor problems interfering with activities of daily life.

\section{CONCLUDING REMARKS}

In children presenting with clumsiness or DCD, the distinction into two types of MND has considerable clinical relevance. Simple MND, which at school-age is the most frequently encountered form of MND, has limited clinical significance (Table 4). Simple MND reflects the presence of a normal, but non-optimally wired brain, which either has a genetic origin or can be attributed to stressful events during early life. Complex MND, on the other hand, can be considered a distinct form of perinatally acquired and more

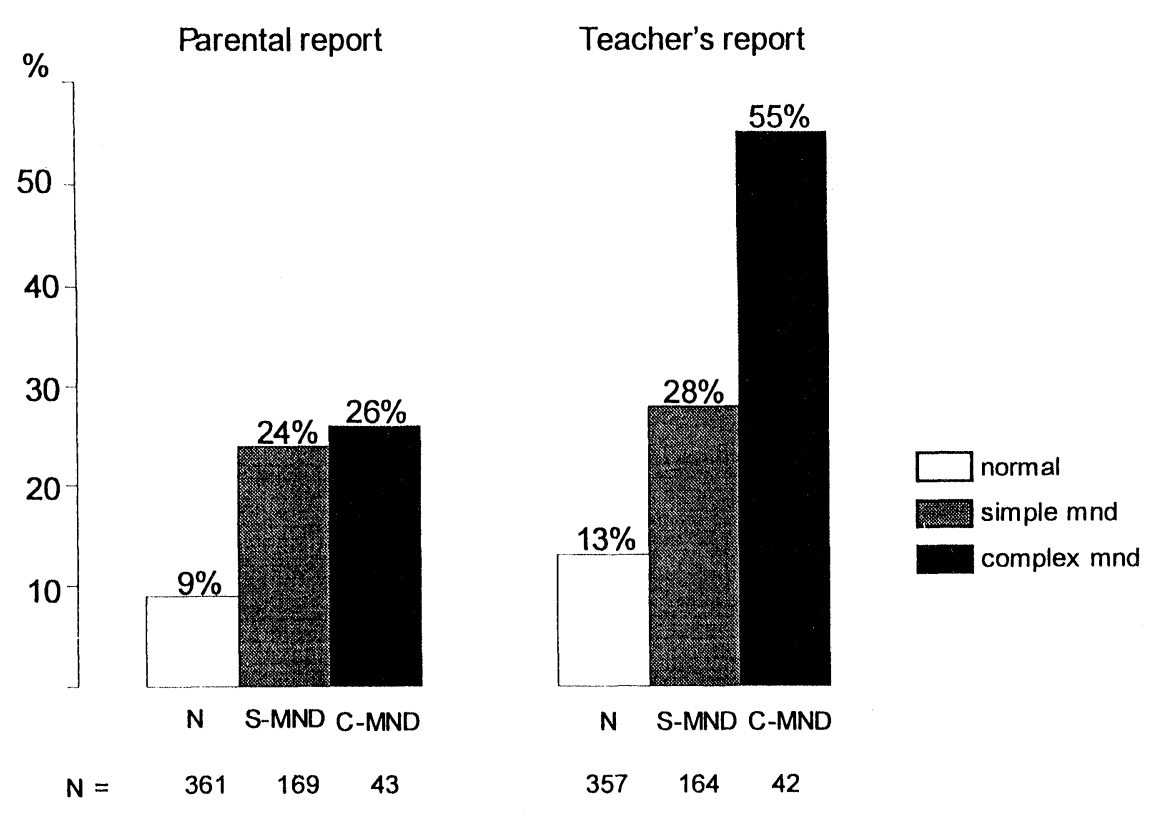

Fig. 1. Data of the Groningen Perinatal Project: relationship between neurological condition and clumsiness reported by parents (left panel) and teachers (right panel) in a group of nine-year-old children (see Hadders-Algra et al. 1988b). 


\section{TABLE 4}

Relation between MND and clumsiness, behavioral and learning problems

\begin{tabular}{|l|c|c|}
\hline & SIMPLE MND & $\begin{array}{c}\text { COMPLEX } \\
\text { MND }\end{array}$ \\
\hline Relation with pre- and perinatal adversities & \pm & +++ \\
\hline Relation with clumsy motor behavior & ++ & +++ \\
\hline $\begin{array}{l}\text { Relation with behavioral problems } \\
\text { (especially ADHD) }\end{array}$ & + & +++ \\
\hline Relation with learning problems & + & +++ \\
\hline
\end{tabular}

$\pm=$ very weak relation, $+=$ weak relation, $++=$ clear relation, +++ very strong relation

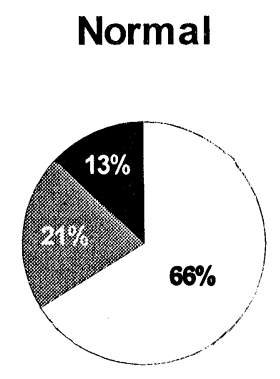

$N=108$
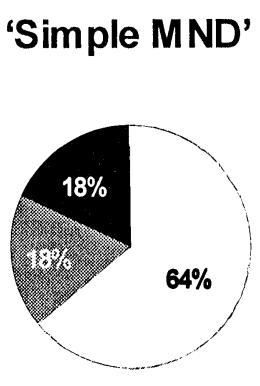

$N=22$

\section{'Complex MND'}

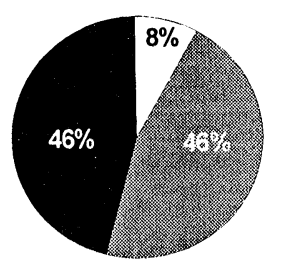

$N=26$

Mov. ABC

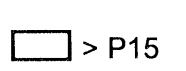

Fig. 2: Neurological condition and performance on the Movement $A B C$ in 6-year-old preterms (Adapted from Jongmans et al. 1997.) The neurological classification is based on the neurological optimality score of the Touwen assessment. Neurologically normal represents an optimality score $>15^{\text {th }}$ percentile, 'simple MND' denotes an optimality score between the $5^{\text {th }}$ and $15^{\text {th }}$ percentile and 'complex MND' indicates the presence of an optimality score $<5^{\text {th }}$ percentile. 
extensive form of brain dysfunction. It has been hypothesized that this form of brain dyfunction might be due to an early lesion in one or more of the connecting fiber systems in the nervous system. The presence of substantial neural dysfunction in children with complex MND is associated with a high chance of the development of motor problems interfering with the activities of daily life and it induces a pronounced vulnerability for the development of other problems, such as specific learning disorders or attention problems (Table 4). Thus is seems that especially children with complex MND deserve our clinical support and attention.

\section{ACKNOWLEDGMENTS}

I thank Bjorg Fallang, Agnes Hornstra, and Roelof Hadders for their critical and valuable remarks on a previous draft of this manuscript. Lidy KingmaBalkema is gratefully acknowledged for technical assistance in the preparation of the figures.

\section{REFERENCES}

Alexander GE, Crutcher MD. 1990. Functional architecture of basal ganglia circuits: neural substrates of parallel processing. Trends Neurosci 13: 266-271.

American Psychiatric Association. 1994. Diagnostic and Statistical Manual of Mental Disorders, $4^{\text {th }}$ ed. Washington, DC, USA: APA; 943.

Cases O, Seif I, Grimsby J, Gaspar P, Chen K, Poumin S, et al. 1995. Aggressive behavior and altered amounts of brain serotonin and norepinephrine in mice lacking MAOA. Science 268: $1763-1766$.

Cases O, Lebrand C, Vitalis T, De Maeyer E, Caron MG, Price DJ, et al. 1998. Plasma membrane transporters of serotonin, dopamine, and norepinephrine mediate serotonin accumulation in atypical locations in the development brain of monoamine oxidase A knock-outs. J Neurosci 18: 6914-6927.
Diamond A. 2000. Close interrelation of motor development and cognitive development and of the cerebellum and prefrontal cortex. Child Dev 71: 44-56.

Fallang B, Saugstad OD, Grøgaard J, Hadders-Algra M. 2003. Kinematic quality of reaching movements in preterm infants. Pediatr Res 53: 836-842.

Faraone SV, Biederman J. 1998. Neurobiology of attention deficit hyperacitivity disorder. Biol Psychiatry 44: 951-958.

Garcia-Segura LM, Azcoitia I, DonCarlos LL. 2001. Neuroprotection by estradiol. Prog Neurobiol 63: 29-60.

Geuze RH, Jongmans MJ, Schoemaker MM, SmitsEngelsman BCM. 2001. Clinical and research diagnostic criteria for developmental coordination disorder: a review and discussion. Hum Mov Sci 20: 7-47.

Gu Q, Singer W. 1995. Involvement of serotonin in developmental plasticity of kitten visual cortex. Eur J Neurosci 7: 1146-1153.

Hadders-Algra M. 2002. Two distinct forms of minor neurological dysfunction: perspectives emerging from a review of data of the Groningen Perinatal Project. Dev Med Child Neurol 44: 561-571.

Hadders-Algra M, Groothuis AMC. 1999. Quality of general movements in infancy is related to neurological dysfunction, ADHD, and aggressive behaviour. Dev Med Child Neurol 41: 381-391.

Hadders-Algra M, Touwen BCL. 1992. Minor neurological dysfunction is more closely related to learning difficulties than to behavioral problems. J Learn Disabil 25: 649-657.

Hadders-Algra M, Brogren E, Katz-Salamon M, Forssberg H. 1999. Periventricular leukomalacia and preterm birth have a different detrimental effect on postural adjustments. Brain 122: 727-740.

Hadders-Algra M, Huisjes HJ, Touwen BCL. 1988a. Perinatal correlates of major and minor neurological dysfunction at schoolage- - a multivariate analysis. Dev Med Child Neurol 30: 472-481.

Hadders-Algra M, Huisjes HJ, Touwen BCL. 1988b. Perinatal risk factors and minor neurological dysfunction: significance for behavior and school achievement at nine years. Dev Med Child Neurol 30: 482-491.

Hadders-Algra M, Mavinkurve-Groothuis AMC, Groen SE, Stremmelaar EF, Martijn A, Butcher PR. 2003. Quality of general movements and the development of minor neurological dysfunction at toddler and school age. Clin Rehab, in press. 
Hampson E. 1990 Estrogen-related variations in human spatial and articulatory-motor skills. Psychoneuroendocrinology 15: 97-111.

Hellerud BC, Storm H. 2002. Skin conductance and behavior during sensory stimulation of preterm and term infants. Early Hum Dev 70: 35-46.

Hempel MS. 1993. The neurological examination for toddler age. Groningen, the Netherlands: $\mathrm{PhD}$ Thesis, University of Groningen; 232.

Henderson SE, Henderson L. 2003. Towards an understanding of developmental coordination disorder: terminology and diagnostic issues. Neural Plast 10: 1-14.

Henderson SE, Sugden DA. 1992. Movement assessment battery for children. Sidcup, UK: The Psychological Corporation; 128.

Herzig ME. 1987. Soft neurological signs. In: Tupper DE, ed, Soft neurological signs. Orlando, Florida, USA: Grune \& Stratton; 355-368.

Holsti L, Grunau RVE, Whitfield MF. 2002. Developmental coordination disorder in extremely low birthweight children at nine years. J Dev Behav Pediatr 23: 9-15.

Huttunen MO, Niskanen P. 1978. Prenatal loss of father and psychiatric disorders. Arch Gen Psychiatry 35: 429-431.

Inder TE, Huppi PS, Warfield S, Kikiniś R, Zientara GP, Barnes PD, Jolesz F, Volpe JJ. 1999. Periventricular white matter injury in the premature infants is followed by reduced cortical gray matter volume at term. Ann Neurol 46: 755-760.

Jacobson M. 1991. Developmental neurobiology, $3^{\text {rd }}$ ed. New York-London: Plenum Press; 776.

Jongmans M, Mercuri E, de Vries L, Dubowitz L, Henderson SE. 1997. Minor neurological signs and perceptual-motor difficulties in prematurely born children. Arch Dis Childh 76: F9-14.

Kajantie E, Phillips DI, Andersson S, Barker DJ, Dunkel L, Forsen T, et al. 2002. Size at birth, gestational age, and cortisol secretion in adult life: foetal programming of both hyper- and hypocortisolism? Clin Endocrinol 57: 635-641.

Lagercrantz H, Ringstedt T. 2001.Organization of the neuronal circuits in the central nervous system during development. Acta Paediatr 90: 707-715.

Leiner HC, Leiner AL, Dow RS. 1993. Cognitive and language functions of the human cerebellum. Trends Neurosci 16: 444-447.

Ley D, Laurin J, Bjerre I, Marsal K. 1996. Abnormal fetal aortic velocity waveform and minor neuro- logical dysfunction at 7 years of age. Ultrasound Obstet Gyencol 8: 152-159.

Lou HC, Hansen D, Nordentoft M, Pryds O, Jensen F, Nim J, Hemmingsen R. 1994. Prenatal stressors of human life affect fetal brain development. Dev Med Child Neurol 36: 826-832.

Lunsing RJ, Hadders-Algra M, Huisjes HJ, Touwen BCL. 1992. Minor neurological dysfunction (MND) from birth to twelve years (II): Puberty is related to a decrease of MND. Dev Med Child Neurol 34: 404-409.

Martini L, Melcangi RC. 1991. Androgen metabolism in the brain. J Steroid Biochem Mol Biol 39: 819-828.

Mercuri E, Jongmans M, Henderson S, Pennock J, Chung YL, De Vries L, Dubowitz L. 1996. Evaluation of the corpus collusum in clumsy children born prematurely: a functional and morphological study. Neuropediatrics 29: 317-322.

Mulder EJH, Robles de Medina PG, Huizink AC, Van den Bergh BRH, Buitelaar JK, Visser GHA. 2002. Prenatal maternal stress: effects on pregnancy and the (unborn) child. Early Hum Dev 70: 3-14.

Peters DAV. 1982. Prenatal stress: effects on brain biogenic amine and plasma corticosterone levels. Pharmacol Biochem Behav 17: 721-725.

Peters DAV. 1988. Both prenatal and postnatal factors contribute to the effects of maternal stress on offspring behavior and central 5-hydroxy tryptamine receptors in the rat. Pharmacol Biochem Behav 30: 669-673.

Peters DAV. 1990. Maternal stress increases fetal brain and neonatal cortex 5-hydroxy tryptamine synthesis in rats: a possible mechanism by which stress influences brain development. Pharmacol Biochem Behav 35: 943-947.

Polatajko H, Fox M, Missiuna C. 1995. An international consensus on children with develop-mental coordination disorder. Can J Occup Ther 62: 3-6.

Schneider ML. 1992a. The effect of mild stress during pregnancy on birthweight and neuromotor maturation in rhesus monkey infants (macaca mulatta). Infant Behav Dev 15: 389-403.

Schneider ML. 1992b. Prenatal stress exposure alters postnatal behavioral expression under conditions of novelty challenge in rhesus monkey infants. Dev Psychobiol 25: 529-540.

Schneider ML. 1992c. Delayed object permanence development in prenatally stressed monkey infants 
(Macaca mulatta). Occup Ther J Res 12: 96-110. Schneider ML, Coe CL. 1993. Repeated social stress during pregnancy impairs neuromotor development of the primate infant. J Dev Behav Pediatr 14: 81-87.

Schneider ML, Clarke AS, Kraemer GW, Roughton EC, Lubach GR, Rimm-Kaufman S, et al. 1998. Prenatal stress alters brain biogenic amine levels in primates. Dev Psychopathol 10: 427-440.

Soorani-Lunsing RJ, Hadders-Algra M, Olinga AA, Huisjes HJ, Touwen BCL. 1993. Minor neurological dysfunction after the onset of puberty: association with perinatal events. Early Hum Dev 33: 71-80.

Soorani-Lunsing RJ, Hadders-Algra M, Huisjes HJ, Touwen BCL. 1994. Neurobehavioural relationships after the onset of puberty. Dev Med Child Neurol 36: 334-343.

Stanley F, Blair E, Alberman E. 2000. Cerebral palsies: epidemiology and causal pathways. Clin Dev Med No. 151. London, UK: Mac Keith Press; 251.

Timiras PS. 1972. Physiologic changes at adolescence.
In: Timiras PS, ed, Developmental Physiology and Aging. New York, NY, USA: Macmillan; 364-374.

Touwen BCL. 1979. Examination of the child with Minor Neurological dysfunction. Clin Dev Med No. 71, London, UK: Heinemann Medical Books; 141.

Touwen BCL. 1987. The meaning and value of soft signs in neurology. In: Tupper DE, ed, Soft neurological signs. Orlando, Florida, USA: Grune \& Stratton; 281-295.

Volpe JJ. 1995. Neurology of the newborn. $3^{\text {rd }}$ ed. Philadelphia, Pennsylvania, USA: WB Saunders; 876.

Watson JB, Mednick SA, Huttunen M, Wang X. 1999. Prenatal teratogens and the development of adult mental illness. Dev Psychopathol 11: 457-466.

Weinstock M. 2001. Alterations induced by gestational stress in brain morphology and behavior of the offspring. Progr Neurobiol 65: 427-451.

Zuckerman B, Bauchner H, Parker S, Cabral H. 1990. Maternal depressive symptoms during pregnancy and newborn irritability. J Dev Behav Pediatr 11: 190-194. 

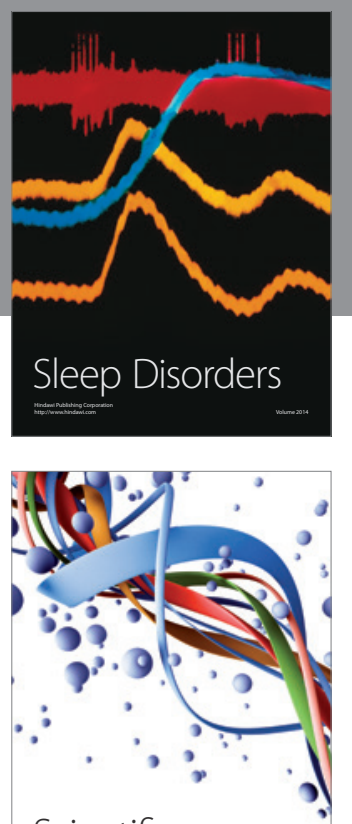

Scientifica
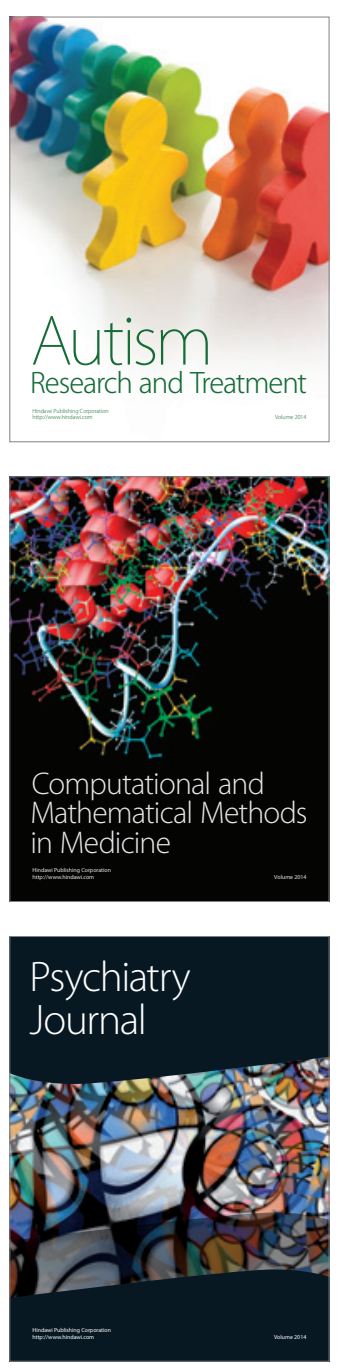
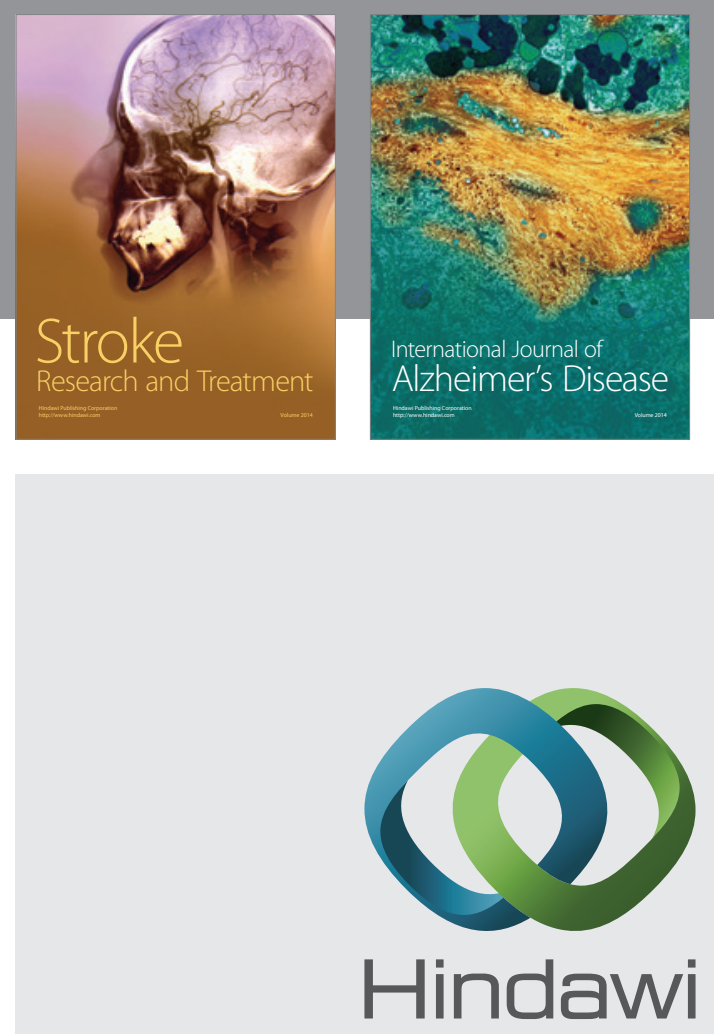

Submit your manuscripts at

http://www.hindawi.com
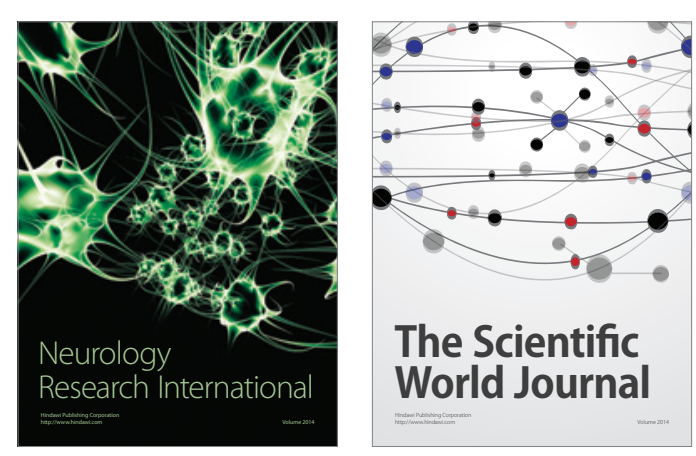

The Scientific World Journal

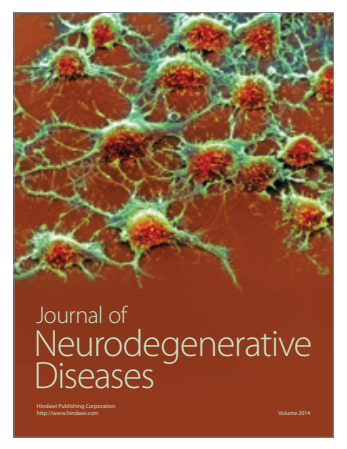

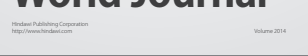

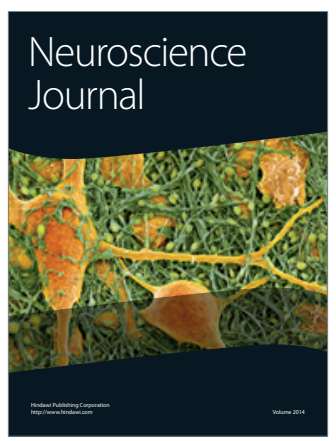

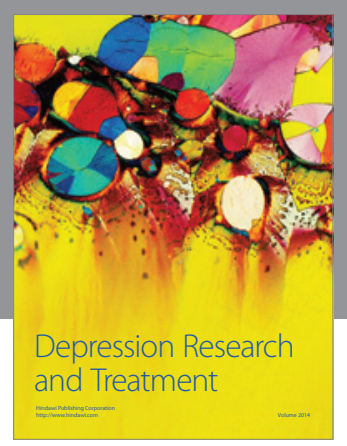
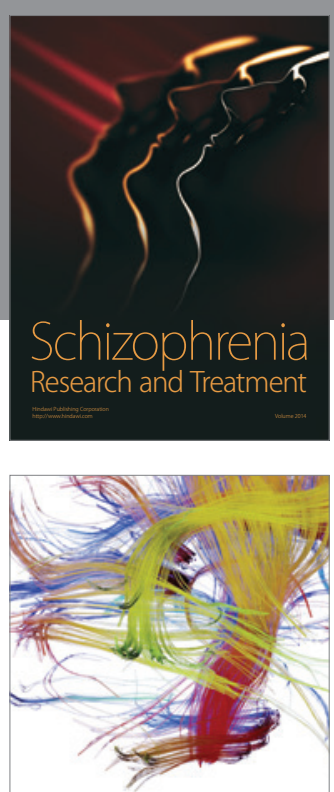

Brain Science

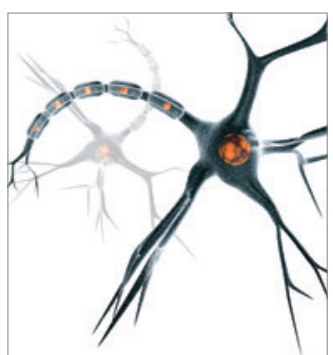

Neural Plasticity
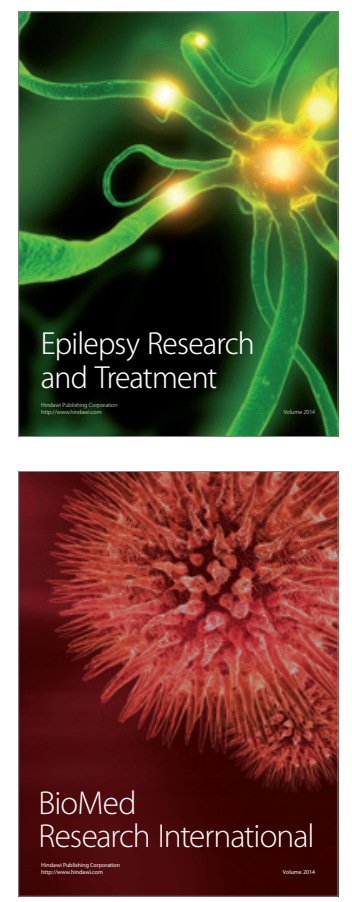

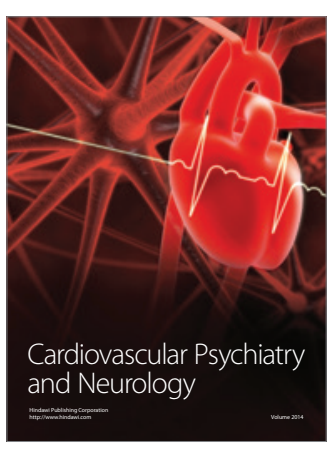

Parkinson's

Disease
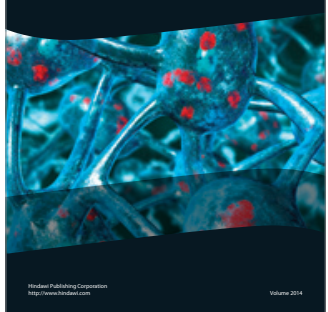